\title{
Effects of Dihydroxy Bile Acids and Hydroxy Fatty Acids on the Absorption of Oleic Acid in the Human Jejunum
}

\author{
Roland Wanitschke and Helmut V. Ammon, Gastroenterology Section, \\ Medical Service, Veterans Administration Center, Wood, Wisconsin \\ 53193, and the Department of Medicine, Medical College of \\ Wisconsin, Milwaukee, Wisconsin 53233
}

\begin{abstract}
A B S T RACT Perfusion studies of the normal human jejunum were performed to test whether dihydroxy bile acids and hydroxy fatty acids inhibit the absorption of oleic acid, since previous reports documented their inhibitory effects on the absorption of several other organic solutes. $3 \mathrm{mM}$ deoxycholate and $7 \mathrm{mM}$ glycodeoxycholate inhibited the absorption of $3 \mathrm{mM}$ oleic acid in isotonic micellar solutions while inducing net fluid secretion. Similarly, fractional absorption of oleic acid decreased in the presence of hydroxy fatty acids. However, only the changes induced by $2 \mathrm{mM}$ ricinoleic acid could be distinguished from changes induced by an increase in total fatty acid concentration. Under all experimental conditions, close linear relationships existed between net water movement and fractional absorption of glucose, xylose, and fatty acids, as well as between the absorption rates of these solutes. In contrast, net fluid secretion induced by hypertonic D-mannitol (450 mosmol/liter) had no effect on solute absorption. Our data and observations in the literature do not allow formulation of a hypothesis which would adequately define all effects of dihydroxy bile acids and fatty acids on intestinal transport processes. The observations help explain the malabsorption of fat and other nutrients in patients with the blind loop syndrome.
\end{abstract}

\section{INTRODUCTION}

Patients with bacterial overgrowth in the small intestine frequently have marked steatorrhea. Generally it is thought that the deconjugation and dehydroxylation of bile salts by bacteria lead to a reduction of the

This paper was published in part in abstract form in 1975 . Gastroenterology. 68: 859.

Dr. Wanitschke's present address is I. Med. Klinik. d. Universität, Langenbeck Str. 1, 6500 Mainz, Germany.

Received for publication 4 May 1976 and in revised form 19 August 1977. effective intraluminal bile salt concentration below the critical micellar concentration resulting in an intraluminal defect of fat absorption (1-3). This concept is based on observations that jejunal bile salt concentrations were low in patients with the blind loop syndrome (4), that feeding of taurocholate (TC) ${ }^{1}$ improved fat absorption in one patient (4) and in experimental animals (5), and that unconjugated deoxycholate (DC) did not specifically inhibit fatty acid absorption in vivo $(1,2)$. However, analysis of postprandial jejunal contents of patients with bacterial overgrowth has shown adequate micellar solubilization of fatty acids (6). In addition, Shimoda et al. (7) demonstrated morphologic changes in the jejunal mucosa compatible with impaired fat absorption when they fed healthy volunteers a fatty meal after infusion of deoxycholate into the jejunum.

Dihydroxy bile acids and long-chain fatty acids induce net fluid secretion when perfused through the intestine of experimental animals $(8-11)$ and man (12-14). When water secretion is induced, electrolytes are secreted in parallel $(9,11,13-15)$, and in addition, absorption of organic solutes is reduced. Dihydroxy bile acids inhibit the absorption of glucose $(8,9,12,13)$ and amino acids (10). Oleic acid (OA) inhibits the absorption of glucose (16); and ricinoleic acid (RA), a hydroxy fatty acid, inhibits the absorption of sugars $(11,16)$, amino acids (16), taurocholate (11), and a lipid, 2 -mono-olein (16). We therefore postulated that dihydroxy bile acids and hydroxy fatty acids might also affect the absorption of fatty acids. Here we report perfusion experiments in which we studied the absorption of oleic acid in comparison with that of glucose and xylose from the human jejunum under control conditions of fluid absorption and during fluid secre-

${ }^{1}$ Abbreviations used in this paper: DC, deoxycholic acid; GDC, glycodeoxycholic acid; HSA, 10-hydroxy stearic acid; OA, oleic acid; PEG, polyethylene glycol; RA, ricinoleic acid; TC, taurocholic acid. 
tion induced by dihydroxy bile acids, hydroxy fatty acids, and hypertonic D-mannitol.

\section{METHODS}

Materials. Conjugated bile acids were synthesized as described previously (17). The conjugated precursors, cholic acid and deoxycholic acid, were purchased from ICN Pharmaceuticals Inc., Life Sciences Group, (Cleveland, Ohio). The purity of the conjugates was greater than $95 \%$, as determined by thin-layer chromatography. Oleic acid (more than 99\% pure) was obtained from Nu-Chek Prep (Elysian, Minn.). Ricinoleic acid (12-hydroxy- $\Delta-9,10$-octadecenoic acid) was prepared by saponification of castor oil with subsequent serial solvent extraction with petrol ether-methanol (14) and contained less than $2 \%$ impurities by gas-liquid and thin-layer chromatography. 10-Hydroxy stearic acid (HSA) was prepared as a mixture of 10- and 9-hydroxy stearic acid according to the method of Knight et al. (18) and was greater than $99 \%$ pure by gas-liquid chromatography (14). [ $\left.{ }^{14} \mathrm{C}\right]$ Polyethylene glycol ([$\left.\left.{ }^{14} \mathrm{C}\right] \mathrm{PEG}\right)$ and $\left[{ }^{3} \mathrm{H}\right]$ polyethylene glycol $\left(\left[{ }^{3} \mathrm{H}\right] \mathrm{PEG}\right)$ were purchased from New England Nuclear (Boston, Mass.), and $\left[{ }^{14} \mathrm{C}\right]$ deoxycholic acid (carboxyl- ${ }^{14} \mathrm{C}$ ) from ICN Pharmaceuticals.

Perfusion technique. The subjects were healthy male volunteers (mean age $22 \mathrm{yr}$ ) who gave informed consent. The perfusion technique, described previously $(12-14,19,20)$, employs a four-lumen tube with an occluding balloon proxi$\mathrm{mal}$ to the perfusion site. The balloon is positioned fluoroscopically at the ligament of Treitz. Perfusates were delivered at $37^{\circ} \mathrm{C}$ at a constant rate of $10 \mathrm{ml} / \mathrm{min}$; they were sampled $25 \mathrm{~cm}$ distally by siphonage. Duodenal contents proximal to the balloon were removed by intermittent suction. An additional gastric tube was inserted for aspiration of gastric secretions. Control and test solutions were perfused for 60 min. The first $30 \mathrm{~min}$ were used for equilibration. Samples were collected for six consecutive 5-min intervals. Steadystate conditions were confirmed by stable concentrations of PEG during these sequential sampling periods, and all results refer to observations during the steady state $(12-14,20)$.

Analytical methods. PEG was measured by determination of $\left[{ }^{14} \mathrm{C}\right] \mathrm{PEG}(21)$ or $\left[{ }^{3} \mathrm{H}\right] \mathrm{PEG}$, and deoxycholate by determination of $\left[{ }^{14} \mathrm{C}\right]$ deoxycholate. For isotope determinations, $1 \mathrm{ml}$ of perfusate or effluent was mixed with $10 \mathrm{ml}$ of a scintillation cocktail composed of toluene and emulsifier (Ready Solv VI, Beckman Instruments, Inc., Fullerton, Calif.) and counted in a liquid scintillation counter (Beckman, model LS-255). Quench correction was made by external standardization. Samples containing two isotopes were counted in two channels. Counts per minute were converted into disintegrations per minute for each isotope with a computer program which corrected for quenching and spillover of ${ }^{14} \mathrm{C}$ into the tritium channel (22). Spillover of tritium into the ${ }^{14} \mathrm{C}$ channel was less than $1 \%$. In order to validate $\left[{ }^{3} \mathrm{H}\right] \mathrm{PEG}$ as a nonabsorbable marker, we added $20 \mu \mathrm{Ci}$ of $\left[{ }^{3} \mathrm{H}\right.$ ]PEG to perfusion solutions and compared the water movements calculated from the $\left[{ }^{14} \mathrm{C}\right] \mathrm{PEG}$ and $\left[{ }^{3} \mathrm{H}\right] \mathrm{PEG}$ data. A very close correlation existed between the values obtained from the two isotopes ( $r=0.991$; regression equation: $y=0.10+0.99 x ; n=24)$. Fatty acids were quantitated by gas-liquid chromatography (14) after acid extraction in toluene-ethanol (2:1) (23). Glucose was determined by the glucose oxidase method (Boehringer Mannheim Biochemicals, Indianapolis, Ind.), and D-xylose by the ortho-toluidine method (24).

Calculations and statistical analysis. Net water and solute movements were calculated by standard formulas from the changes in PEG concentrations and solute concentrations between perfusion solutions and collected samples (21). Net water movement is expressed as milliliters per minute per $25 \mathrm{~cm}$ and solute absorption as micromoles per minute per $25 \mathrm{~cm}$ or in percent (fractional adsorption) as the mean of six consecutive 5-min collection periods. Over the sequential 5min sampling periods, the dispersion of PEG concentration and solute transport (SEM/mean $\times 100)(13)$ was $1.3 \%$ for PEG (range $0.3-4.5 \%$ ), $4.2 \%$ for glucose (range $0.7-9.6 \%$ ), $10.2 \%$ for xylose (range $1.5-26.8 \%$ ), and $5.4 \%$ for fatty acids (range 0.3-20.7\%). Differences in net movement of water and absorption of solutes were evaluated statistically by paired and unpaired Student's $t$ tests. Linear regressions were calculated by the method of least squares (25).

Experimental design and composition of perfusion solutions. Three groups of experiments were performed using micellar solutions of bile acids and fatty acids. All perfusion solutions contained (in millimoles per liter): $\mathrm{NaCl}, 100$; $\mathrm{KCl}, 5$; $\mathrm{NaHCO}_{3}, 10$; D-glucose, 11.2; D-xylose, 11.2; and PEG-4000, 5 g/liter; $\left[{ }^{14} \mathrm{C}\right] \mathrm{PEG}, 5 \mu \mathrm{Ci} /$ liter; or $\left[{ }^{3} \mathrm{H}\right] \mathrm{PEG}, 20$ $\mu \mathrm{Ci} /$ liter. The solutions were adjusted with $\mathrm{NaCl}$ to isotonicity ( $280 \mathrm{mosmol} / \mathrm{liter}$ ) at $\mathrm{pH} 7.4$ after the addition of sodium salts of bile acids and fatty acids as outlined below. Analysis for $\mathrm{Na}, \mathrm{K}, \mathrm{Cl}$, glucose, and xylose showed no significant differences in the concentrations of these solutes between the perfusion solutions.

Group A: Effects of glycodeoxycholic acid (GDC) and a hydroxy fatty acid, RA, on OA absorption. The influence of net fluid secretion induced by dihydroxy bile acids and hydroxy fatty acids on the absorption of OA was tested in five volunteers using four perfusion solutions in random sequence. The control solution (I) contained $7 \mathrm{mM}$ TC and 3 mM OA (TC 7, OA 3). TC was used for micellar solubilization of the fatty acids. In the concentrations used in the current experiments, it had no effect on intestinal water transport (14). In solution II, we measured the absorption of $3 \mathrm{mM}$ OA in the presence of a conjugated dihydroxy bile acid, $7 \mathrm{mM}$ GDC (GDC 7, OA 3). Solution III tested the effect of RA on OA absorption and contained $7 \mathrm{mM} \mathrm{TC}$, $3 \mathrm{mM} \mathrm{OA}$, and $6 \mathrm{mM}$ RA (TC 7, OA 3, RA 6). Solution IV contained $7 \mathrm{mM}$ TC and $9 \mathrm{mM}$ OA (TC 7, OA 9) as the appropriate control for the increased fatty acid load. In one volunteer, solution III was omitted from the perfusion sequence.

Group B: Effects of deoxycholate and hydroxy fatty acids on OA absorption. Study B was designed to simulate conditions which might occur in the blind loop syndrome. Absorption of $\mathrm{OA}$ was measured under six different experimental conditions in six healthy volunteers. The solutions were perfused in random sequence. Solution I (control) contained 10 $\mathrm{mM}$ TC and $3 \mathrm{mM}$ OA (TC 10 , OA 3 ); solution II contained $7 \mathrm{mM}$ TC, $3 \mathrm{mM}$ DC, and $3 \mathrm{mM}$ OA (TC 7, DC 3 , OA 3) (part of TC was replaced by DC to simulate bacterial deconjugation and dehydroxylation of bile acids); solution III contained $10 \mathrm{mM}$ TC, $3 \mathrm{mM} \mathrm{OA}$, and $2 \mathrm{mM}$ HSA (TC 10 , OA 3, HSA 2). HSA was added, since this compound is the product of bacterial action on OA (26) and since it theoretically could be present in the upper small intestine in states of bacterial overgrowth. Solution IV contained $7 \mathrm{mM}$ TC, 3 $\mathrm{mM}$ DC, $3 \mathrm{mM} \mathrm{OA}$, and $2 \mathrm{mM}$ HSA (TC 7, DC 3, OA 3, HSA 2) to study the combined presence of DC and HSA on OA absorption. In solution V, HSA was replaced by RA (TC 10, OA 3, RA 2). Solution VI contained $10 \mathrm{mM}$ TC and $5 \mathrm{mM}$ OA (TC 10, OA 5) as control for the increased fatty acid load in solutions III, IV, and V. Solutions II and IV contained $\left[{ }^{14} \mathrm{C}\right]$ deoxycholate $(5 \mu \mathrm{Ci} /$ liter $)$ and $\left[{ }^{3} \mathrm{H}\right]$ PEG $(20 \mu \mathrm{Ci} /$ liter $)$ instead of $\left[{ }^{14} \mathrm{C}\right] \mathrm{PEG}$. In one subject, solutions II and $\mathrm{V}$ had to be omitted from the perfusion sequence.

Group C: Effects of osmotically induced net fluid secretion 


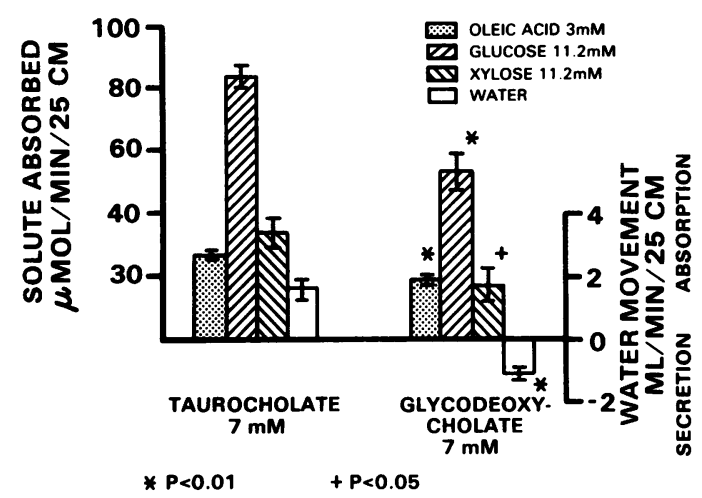

FIGURE 1 Effects of glycodeoxycholate on net water movement and solute absorption in the human jejunum in comparison with taurocholate. Data from studies in five healthy volunteers. Isotonic electrolyte solutions were perfused at $10 \mathrm{ml} / \mathrm{min}$ over a $25-\mathrm{cm}$ test segment. Values are mean $\pm \mathrm{SE}$.

on absorption of fatty acids. To determine whether changes in solute absorption were induced by changes in net water movement, mannitol was used to produce osmotic water flow. In four volunteers, we compared the absorption of OA, glucose, and xylose from an isotonic solution containing $10 \mathrm{mM}$ TC and $3 \mathrm{mM}$ OA ( $280 \mathrm{mosmol} /$ liter) (identical with solution $I$ in B) with a solution containing, in addition, D-mannitol to an osmolality of $450 \mathrm{mosmol} / \mathrm{liter}$.

\section{RESULTS}

Net water transport. Water was absorbed during perfusion with the control solutions containing $3 \mathrm{mM}$ OA (Figs. 1 and 2 and Table I). Net fluid secretion occurred under all other test conditions: i.e., in the presence of dihydroxy bile acids and hydroxy fatty acids, in the presence of increasing concentrations of $\mathrm{OA}$, and in response to an osmotic gradient. Net fluid secretion in the presence of mannitol $(4.7 \pm 0.7 \mathrm{ml} / \mathrm{min}$ per $25 \mathrm{~cm})$ (Table I) was significantly greater $(P<0.05)$ than during perfusion with $9 \mathrm{mM} \mathrm{OA}(2.7 \pm 0.4) \mathrm{ml} / \mathrm{min}$ per $25 \mathrm{~cm}$ ) (Fig. 3), which induced the greatest net fluid secretion in group A or B.

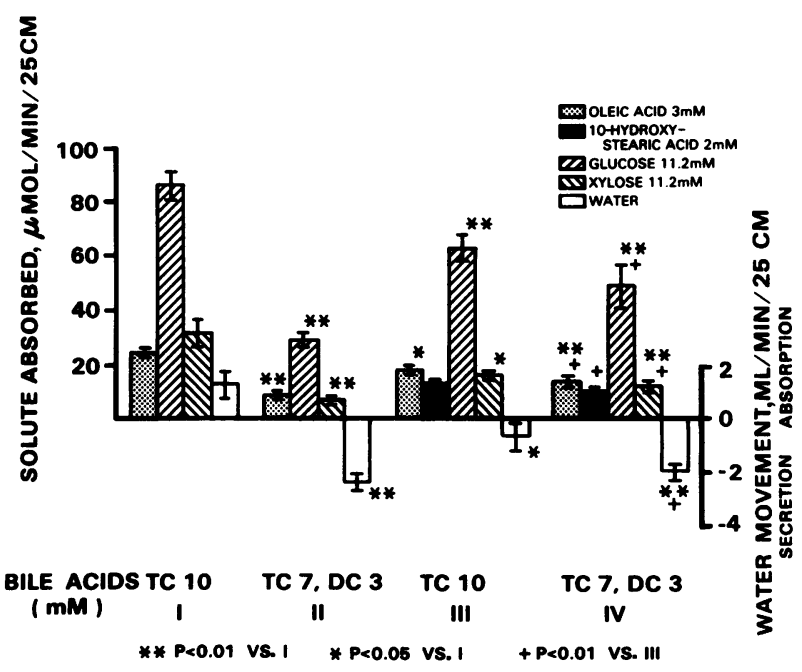

FIGURE 2 Effects of deoxycholate on net water movement and solute absorption in the human jejunum. Data from studies in six volunteers. (Solution II had to be omitted in one study.) Isotonic electrolyte solutions were perfused at $10 \mathrm{ml} / \mathrm{min}$ over a 25 -cm test segment. Values are mean $\pm \mathrm{SE}$. $\mathrm{TC}=$ taurocholate $; \mathrm{DC}=$ deoxycholate.

Absorption of monosaccharides. As in previous studies $(8,9,11-13,16)$, absorption of glucose and xylose decreased whenever absorption changed to net fluid secretion in the presence of dihydroxy bile acids or fatty acids (Figs. 1, 2, and 3). In the presence of conjugated or unconjugated DC, RA, HSA, and $9 \mathrm{mM}$ $\mathrm{OA}$, these changes were statistically significant $(P$ $<0.05)$. Under these experimental conditions, glucose concentrations in the effluents and therefore mean segment concentrations of glucose were either unchanged or increased $(P<0.01)$ in comparison with the respective controls (Table II). The mean segment concentrations of xylose were slightly reduced in comparison with the control solutions; however, these changes were only significant during perfusion with $9 \mathrm{mM} \mathrm{OA}$ and with GDC 7, OA $3(P<0.05)$ (Table II).

Effects of bile acids on absorption of fatty acids.

TABLE I

Effect of Osmotically Induced Fluid Secretion on Absorption of Oleate (3 mM), Glucose (11.2 mM), and Xylose (11.2 mM)

\begin{tabular}{|c|c|c|c|c|c|c|c|}
\hline \multirow[b]{2}{*}{ Test circumstances } & \multicolumn{4}{|c|}{ Absorption $/ 25 \mathrm{~cm}$ jejunum } & \multicolumn{3}{|c|}{ Mean segment concentration } \\
\hline & Water* & Oleic acid & Glucose & Xylose & Oleic acid & Glucose & Xylose \\
\hline & $\mathrm{ml} / \mathrm{min}$ & $\mu \mathrm{mol} / \mathrm{min}$ & $\mu \mathrm{mol} / \mathrm{min}$ & $\mu \mathrm{mol} / \mathrm{min}$ & $\mu \mathrm{mol} / \mathrm{ml}$ & $\mu \mathrm{mol} / \mathrm{ml}$ & $\mu \mathrm{mol} / \mathrm{ml}$ \\
\hline Control (280 mosmol/liter) & $0.7 \pm 0.4$ & $25.3 \pm 1.4$ & $85.6 \pm 2.8$ & $31.6 \pm 5.5$ & $1.8 \pm 0.1$ & $6.0 \pm 0.4$ & $10.1 \pm 0.3$ \\
\hline Control + mannitol (450 mosmol/liter) & $-4.3 \pm 0.4$ & $26.8 \pm 0.7$ & $81.2 \pm 4.0$ & $21.6 \pm 4.0 \S$ & $1.6 \pm 0.0$ & $5.6 \pm 0.4$ & $9.0 \pm 0.4^{\prime \prime}$ \\
\hline
\end{tabular}

Each value is mean $( \pm \mathrm{SEM})$ from studies in random sequence in four subjects. All solutions contain $10 \mathrm{mM}$ taurocholic acid.

$*-=$ net fluid secretion.

$\ddagger P<0.01$ vs. control.

$\S$ Not significantly different from control.

" $P<0.05$ vs. control. 


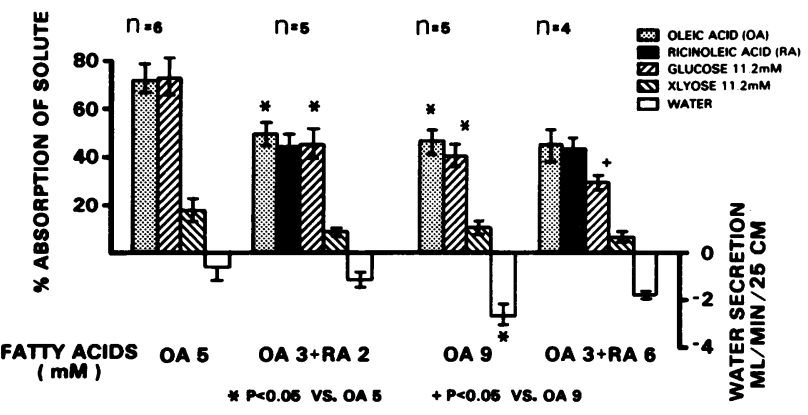

FIgURE 3 Effect of ricinoleic acid and increasing concentrations of oleic acid on net water movement and fractional absorption of solutes in the human jejunum. Data from studies in 11 volunteers (group $A$, solutions I and II; group B, solutions III and IV). (Solutions II and IV had to be omitted in one study each.) Isotonic electrolyte solutions were perfused at $10 \mathrm{ml} / \mathrm{min}$ over a $25-\mathrm{cm}$ test segment. (Solutions I and II contained $7 \mathrm{mM}$ taurocholate, solutions III and IV $10 \mathrm{mM}$ taurocholate.) Values are mean $\pm \mathrm{SE}$.

$7 \mathrm{mM}$ GDC significantly reduced the absorption of $\mathrm{OA}$ in comparison with $7 \mathrm{mM}$ TC $(P<0.01)$ (Fig. 1). Similarly, $3 \mathrm{mM}$ DC significantly inhibited the absorption of $3 \mathrm{mM} \mathrm{OA}(P<0.01)$ (Fig. 2) and of a mixture of $3 \mathrm{mM}$ OA and $2 \mathrm{mM}$ HSA $(P<0.01)$ (Fig. 2$)$ in comparison with the respective controls. Under these conditions, absorption of DC was $8.1 \pm 0.6 \mu \mathrm{mol} / \mathrm{min}$ per 25 $\mathrm{cm}$ and $10.2 \pm 1.8 \mu \mathrm{mol} / \mathrm{min}$ per $25 \mathrm{~cm}$, respectively. Absorption of $3 \mathrm{mM} \mathrm{OA}$ in the presence of $7 \mathrm{mM}$ TC was $25.6 \pm 0.6 \mu \mathrm{mol} / \mathrm{min}$ per $25 \mathrm{~cm}$ (Fig. 1). This was not different from the absorption of $25.2 \pm 0.8 \mu \mathrm{mol} /$ min per $25 \mathrm{~cm}$ observed in the presence of $10 \mathrm{mM}$ TC (Fig. 2, Table I). When fatty acid absorption was reduced by dihydroxy bile acids, mean segment concentration of $\mathrm{OA}$ was increased $(P<0.05)$ (Table II).

Relationship of initial OA concentration and absorption of OA. Fractional absorption of OA decreased from $85 \pm 2.1 \%$ in the presence of $3 \mathrm{mM} \mathrm{OA}$ (group A) to $49.8 \pm 5.4 \%$ in the presence of $9 \mathrm{mM} \mathrm{OA}(P<0.01)$. The latter value was also significantly different from the $71.5 \pm 6.1 \%$ observed in the presence of $5 \mathrm{mM} \mathrm{OA}$ $(P<0.05)$ (Fig. 3).

Effect of HSA on absorption of OA (Fig. 2). In the presence of $10 \mathrm{mM}$ TC, the addition of $3 \mathrm{mM} \mathrm{HSA}$ (solution III) reduced the absorption of $\mathrm{OA}$ in comparison with a solution containing $3 \mathrm{mM}$ OA alone (solution I) $(P<0.05)$. However, total fatty acid absorption from solution III $(31.1 \pm 2.6 \mu \mathrm{mol} / \mathrm{min}$ per $25 \mathrm{~cm})$ was not different from a solution with identical total fatty acid concentration, $5 \mathrm{mM}$ OA $(35.8 \pm 3.1 \mu \mathrm{mol} /$ $\min$ per $25 \mathrm{~cm}$ ) (Fig. 3). In contrast, in the presence of $7 \mathrm{mM} \mathrm{TC}+3 \mathrm{mM}$ DC, the addition of $2 \mathrm{mM}$ HSA slightly reduced net fluid secretion and enhanced the absorption of OA, glucose, and xylose (solution IV vs. solution II, Fig. 2). These changes, however, were not statistically significant.

Effect of RA on solute absorption (Fig. 3). Because of the changing fatty acid concentration, absorption rates in Fig. 3 are expressed as fractional absorption. 2 and $6 \mathrm{mM}$ RA reduced the absorption of $3 \mathrm{mM} \mathrm{OA}$ significantly from $24.8 \pm 1.1 \mu \mathrm{mol} / \mathrm{min}$ per $25 \mathrm{~cm}$ (Fig. 2) to $15.2 \pm 1.3 \mu \mathrm{mol} / \mathrm{min}$ per $25 \mathrm{~cm}$ and $13.4 \pm 1.8 \mu \mathrm{mol} /$

TABLE II

Mean Segment Concentrations of Solutes during Jejunal Perfusion Experiments with Bile Acids and Long-Chain Fatty Acids

\begin{tabular}{|c|c|c|c|c|c|}
\hline \multirow{2}{*}{$\begin{array}{l}\text { Test circumstances } \\
\text { (bile acids and fatty } \\
\text { acids in } \mathrm{mM} \text { ) }\end{array}$} & \multirow[b]{2}{*}{$n$} & \multicolumn{4}{|c|}{ Mean segment concentration $(\mu \mathrm{mol} / \mathrm{ml})$} \\
\hline & & $\begin{array}{l}\text { Oleic } \\
\text { acid }\end{array}$ & $\begin{array}{c}\text { Hydroxy } \\
\text { fatty acid }\end{array}$ & $\begin{array}{l}\text { Glucose, } \\
11.2 \mathrm{mM}\end{array}$ & $\begin{array}{c}\text { Xylose, } \\
11.2 \mathrm{mM}\end{array}$ \\
\hline \multicolumn{6}{|l|}{ Group A } \\
\hline I. TC 7, OA 3 & 5 & $1.8 \pm 0.1$ & & $6.3 \pm 0.3$ & $10.0 \pm 0.1$ \\
\hline II. GDC 7, OA 3 & 5 & $2.0 \pm 0.1^{*}$ & & $7.4 \pm 0.4 !$ & $9.3 \pm 0.2^{*}$ \\
\hline III. TC 7, OA 3, RA 6 & 4 & $2.2 \pm 0.1^{*}$ & $4.4 \pm 0.2$ & $8.2 \pm 0.4 \ddagger$ & $9.5 \pm 0.1$ \\
\hline IV. TC 7, OA 9 & 5 & $6.3 \pm 0.2$ & & $6.9 \pm 0.4$ & $8.8 \pm 0.3^{*}$ \\
\hline \multicolumn{6}{|l|}{ Group B } \\
\hline I. TC 10, OA 3 & 6 & $1.8 \pm 0.7$ & & $6.3 \pm 0.2$ & $9.9 \pm 0.3$ \\
\hline II. TC 7, DC 3, OA 3 & 5 & $2.4 \pm 0.1 \hbar$ & & $8.2 \pm 0.2 \ddagger$ & $9.3 \pm 0.2$ \\
\hline III. TC 10, OA 3, HSA 2 & 6 & $2.0 \pm 0.1$ & $1.3 \pm 0.1$ & $7.4 \pm 0.2 \ddagger$ & $9.6 \pm 0.3$ \\
\hline IV. TC 7, DC 3, OA 3, HSA 2 & 6 & $2.2 \pm 0.1^{*}$ & $1.5 \pm 0.1$ & $7.9 \pm 0.4 \ddagger$ & $9.4 \pm 0.2$ \\
\hline V. TC 10, OA 3, RA 2 & 5 & $2.2 \pm 0.1 \ddagger$ & $1.5 \pm 0.1$ & $7.8 \pm 0.2 \ddagger$ & $9.6 \pm 0.1$ \\
\hline VI. TC 10, OA 5 & 6 & $3.2 \pm 0.1$ & & $6.6 \pm 0.3$ & $9.4 \pm 0.3$ \\
\hline
\end{tabular}

Values are means $( \pm \mathrm{SEM})$; solutions were perfused in random sequence in two groups of experiments.

* $P<0.05$, test vs. I of corresponding group.

$\ddagger P<0.01$, test vs. I of corresponding group. 
min per $25 \mathrm{~cm}$, respectively (Fig. 3$)(P<0.01)$. Absorption rates of RA were $9.0 \pm 1.0 \mu \mathrm{mol} / \mathrm{min}$ per $25 \mathrm{~cm}$ during perfusion with $2 \mathrm{mM} \mathrm{RA}$ and $26.1 \pm 3.7 \mu \mathrm{mol} / \mathrm{min}$ per $25 \mathrm{~cm}$ in the presence of $6 \mathrm{mM}$ RA. Glucose absorption changed from $83.5 \pm 4.8 \mu \mathrm{mol} / \mathrm{min}$ per $25 \mathrm{~cm}$ in the presence of $3 \mathrm{mM} \mathrm{OA}$ alone (Fig. 2) to $30.4 \pm 3.2$ $\mu \mathrm{mol} / \mathrm{min}$ per $25 \mathrm{~cm}$ in the presence of OA 3 , RA 6 $(P<0.01)$ (Fig. 3). Xylose absorption changed from $31.7 \pm 5.3 \mu \mathrm{mol} / \mathrm{min}$ per $25 \mathrm{~cm}$ to $8.0 \pm 2.2 \mu \mathrm{mol} / \mathrm{min}$ per $25 \mathrm{~cm}$ under the corresponding conditions $(P<0.05)$. The differences in total fatty acid absorption, absorption of glucose, and fractional absorption of OA remained significant when absorption rates from the solution containing $2 \mathrm{mM} \mathrm{RA}+3 \mathrm{mM}$ OA were compared with a solution of identical fatty acid concentration, $5 \mathrm{mM}$ OA $(P<0.05)$. On the other hand, total fatty acid absorption and fractional absorption of OA from 6 $\mathrm{mM}$ RA $+3 \mathrm{mM}$ OA were not different from $9 \mathrm{mM}$ OA. Fractional absorption rates of RA and OA were equal when the two fatty acids were perfused together.

Relationships between net water movement and solute absorption (Table III). The data obtained from experiments in groups A and B were pooled and analyzed to study the relationships between changes in net water movement and fractional absorption (percent absorption) of fatty acids, glucose, and xylose induced by dihydroxy bile acids (Table III, group I), increasing amounts of OA (Table III, group II), and the addition of RA (Table III, group III). Since fatty acid concentration varied in the perfusion solutions, fractional absorption rates were used for these calculations; this allowed the comparison of relative absorption rates of solutes present in varying concentrations. In each group, a close correlation existed between net water movement and the fractional absorption of glucose, xylose, and fatty acids. The slope of the regression line for water and glucose in the presence of increasing amounts of OA was significantly lower than the slopes determined in the presence of rising concentrations of RA $(P<0.005)$ and in the presence of dihydroxy bile acids $(P<0.05)$. Xylose, which is more slowly absorbed than glucose, was significantly less af-

TABLE III

Relationships between Net Water Movement ( $\mathrm{ml} / \mathrm{min}$ ) and Solute Absorption (\%) in the Presence of Dihydroxy Bile Acids and Fatty Acids in the Human Jejunum

\begin{tabular}{|c|c|c|c|c|c|c|c|}
\hline \multirow{2}{*}{$\begin{array}{l}\text { Test conditions used for } \\
\text { regression analysis } \\
\text { (Bile acids and fatty acids } \\
\text { in mmol/liter) }\end{array}$} & \multirow[b]{2}{*}{$n$} & \multicolumn{2}{|c|}{ Relationship tested } & \multicolumn{4}{|c|}{$y=a x+b$} \\
\hline & & $x$ & $y$ & $a$ & $b$ & $r$ & $P$ \\
\hline \multirow{6}{*}{$\begin{array}{l}\text { I. TC } 10, \text { OA } 3 \\
\text { TC } 7, \text { OA } 3 \\
\text { GDC } 7, \text { OA } 3 \\
\text { TC } 7, \text { DC } 3 \text {, OA } 3\end{array}$} & 21 & Water & OA & $10.28^{*}$ & 66.67 & 0.80 & $<0.001$ \\
\hline & & Water & Glucose & $12.03 \ddagger$ & 62.07 & 0.87 & $<0.001$ \\
\hline & & Water & Xylose & $6.31 * \S$ & 21.13 & 0.85 & $<0.001$ \\
\hline & & $\mathrm{OA}$ & Glucose & 1.00 & -4.84 & 0.93 & $<0.001$ \\
\hline & & $\mathrm{OA}$ & Xylose & 0.43 & -7.21 & 0.73 & $<0.001$ \\
\hline & & Glucose & Xylose & 0.46 & -7.35 & 0.85 & $<0.001$ \\
\hline \multirow{6}{*}{$\begin{array}{l}\text { II. TC } 10, \text { OA } 3 \\
\text { TC } 7 \text {, OA } 3 \\
\text { TC } 10 \text {, OA } 5 \\
\text { TC } 7 \text {, OA } 9\end{array}$} & 22 & Water & OA & 6.67 & 73.03 & 0.77 & $<0.001$ \\
\hline & & Water & Glucose & 7.99 & 70.68 & 0.85 & $<0.001$ \\
\hline & & Water & Xylose & $4.80^{\prime \prime}$ & 23.08 & 0.77 & $<0.001$ \\
\hline & & $\mathrm{OA}$ & Glucose & 1.0 & -2.16 & 0.92 & $<0.001$ \\
\hline & & $\mathrm{OA}$ & Xylose & 0.52 & -14.56 & 0.72 & $<0.001$ \\
\hline & & Glucose & Xylose & 0.53 & -14.58 & 0.80 & $<0.001$ \\
\hline \multirow{6}{*}{$\begin{array}{l}\text { III. TC } 10, \text { OA } 3 \\
\text { TC } 7 \text {, OA } 3 \\
\text { TC } 10 \text {, OA } 3 \text {, RA } 2 \\
\text { TC } 7 \text {, OA } 3 \text {, RA } 6\end{array}$} & 20 & Water & Fatty acids & $10.08^{*}$ & 65.35 & 0.81 & $<0.001$ \\
\hline & & Water & Glucose & 13.45 I & 60.33 & 0.92 & $<0.001$ \\
\hline & & Water & Xylose & $7.33 * \S$ & 19.25 & 0.93 & $<0.001$ \\
\hline & & Fatty acids & Glucose & 1.07 & -9.30 & 0.91 & $<0.001$ \\
\hline & & Fatty acids & Xylose & 0.48 & -11.90 & 0.76 & $<0.001$ \\
\hline & & Glucose & Xylose & 0.45 & -7.90 & 0.84 & $<0.001$ \\
\hline
\end{tabular}

Linear regressions were calculated from data obtained during perfusion of $25 \mathrm{~cm}$ of jejunum (10 $\mathrm{ml} / \mathrm{min}$ ) with isotonic electrolyte solutions containing $11.2 \mathrm{mM}$ glucose and $11.2 \mathrm{mM}$ xylose.

* Not different from corresponding value in solution II.

$\ddagger P<0.05$, group I vs. group II.

$\S P<0.005$, water/glucose vs. water/xylose within group I and III.

" $P<0.05$, water/glucose vs. water/xylose in group II.

II $P<0.005$, group III vs. group II. 
fected by the changes in water movement, as indicated by the lower slopes of the regression lines for xylose in comparison to glucose in each experimental group $(P<0.05)$. A close linear correlation existed between the changes in fatty acid absorption and those of either glucose or xylose and between the absorption of glucose and xylose under all experimental conditions.

Effects of mannitol-induced fluid secretion on solute absorption (Table I). During perfusion with the hypertonic mannitol solution, absorption rates of $\mathrm{OA}$ and glucose were unchanged. Xylose absorption was somewhat reduced, but the changes were not statistically significant. Mean segment concentrations for these solutes were also essentially unchanged, except for a small reduction in xylose concentration.

\section{DISCUSSION}

Our studies demonstrate that dihydroxy bile acids inhibit the absorption of fatty acids in addition to their established inhibitory effects on water transport and on absorption of nonmicellar solutes (8-16). They further document that the fractional absorption of fatty acids decreases with increasing fatty acid load and that this decrease correlates well with the simultaneously observed changes in glucose absorption and net water movement.

Effects of dihydroxy bile acids on fatty acid absorption. Our observations that conjugated and unconjugated dihydroxy bile acids reduce fatty acid absorption differ from previously reported experiments which addressed the same question $(1,2)$. Cheney et al. (2) used a lower DC concentration $(2 \mathrm{mM})$ and studied the absorption of $1 \mathrm{mM}$ palmitate at a relatively slow perfusion rate in the rat. The smaller fatty acid load, the lower mean segment concentration of DC, and possibly, species differences may account for the different results. The effect of DC on water transport and the absorption of sugars and fatty acids was mitigated by the addition of $2 \mathrm{mM}$ HSA (Fig. 2, solution II vs. solution IV). This observation is in agreement with the observation that addition of fatty acids and mono-olein reduces the effects of DC on water and solute transport in micellar solutions, presumably by expanding micellar size and thereby reducing monomer activity of DC (27).

Changing fatty acid concentration and fatty acid absorption. Two observations require explanation: (a) As in an earlier report (14), we observed a decrease in the fractional absorption of $\mathrm{OA}$ with increasing fatty acid concentration, suggesting a saturable absorption process. (b) Addition of $2 \mathrm{mM}$ RA reduced total fatty acid absorption significantly, while paradoxically, $6 \mathrm{mM}$ RA had no significant effect. These observations are in apparent conflict with the concept that fatty acid absorption from micellar solutions in the jejunum is a diffusion-limited process (28-30). Possible explanations to be considered are changes in micellar size and saturation phenomena of uptake and exit.

Expansion of micellar size. If expansion of micellar size explained the reduction in fractional absorption of $\mathrm{OA}$ in the presence of increasing $\mathrm{OA}$ concentrations or after addition of hydroxy fatty acids, fatty acid absorption from a solution containing $5 \mathrm{mM} O A$ should not be different from the one containing $3 \mathrm{mM}$ OA plus 2 mM RA. Further, the addition of HSA should reduce absorption of $3 \mathrm{mM} \mathrm{OA}$, not only in the presence of $10 \mathrm{mM}$ TC but also in the presence of $7 \mathrm{mM}$ TC plus $3 \mathrm{mM}$ DC. In addition, expansion of micellar size by TC should result in a lower absorption of $\mathrm{OA}$ from a solution containing $10 \mathrm{mM}$ TC in comparison with $7 \mathrm{mM}$ TC (29). The experimental data, therefore, do not support this explanation.

Saturation of the absorptive mechanisms for fatty acids. Since net absorption of fatty acids is the result of uptake from micellar solutions, possible binding to a cytoplasmic fatty acid binding protein (31), resynthesis to triglycerides, chylomicron formation, and subsequent release of the chylomicrons into the lymphatics (32), the later steps in this sequence could become rate limiting in the presence of dihydroxy bile acids or hydroxy fatty acids. If saturation of a ratelimiting step or inhibition of an enzymatic reaction were the explanation for the reduced fatty acid absorption in the presence of hydroxy fatty acids or dihydroxy bile acids (33), absorption of OA from $3 \mathrm{mM}$ OA plus $2 \mathrm{mM}$ HSA should have been lower than from $\mathrm{OA}$ alone, not only in the presence of $10 \mathrm{mM}$ TC but also in the presence of $7 \mathrm{mM}$ TC plus $3 \mathrm{mM}$ DC. Moreover, when fatty acid-induced fluid secretion was reduced by the addition of $56 \mathrm{mM}$ glucose to the perfusion solutions, we observed a significant increase in the absorption of $7 \mathrm{mM} \mathrm{OA} \mathrm{(34).} \mathrm{Satura-}$ tion of potentially rate-limiting steps in the process of fatty acid absorption is, therefore, not an explanation for these observations. Since fractional absorption of OA changes in close correlation with the absorption of glucose and xylose under all experimental conditions (Table III, Fig. 3), we believe that the apparent "saturation" of fatty acid absorption is an expression of the general reduction in solute absorption in the presence of fatty acids which in turn is related to changes in water movement. The paradoxical response in the absorption of $\mathrm{OA}$ to the addition of $2 \mathrm{mM}$ and $6 \mathrm{mM}$ RA can be explained by the different dose response curves for the effects of OA and RA on water movement (14). RA has a more potent effect on water transport at the lower concentrations in comparison to $\mathrm{OA}$, while at higher 
concentrations both fatty acids affect water transport to a similar degree (14).

Possible mechanisms for the observed reduction in solute absorption in the presence of dihydroxy bile acids or fatty acids. Since dihydroxy bile acids and fatty acids affect water and solute transport in identical patterns, all further considerations about possible mechanisms apply to both classes of compounds.

Change in transit time. Acceleration of intestinal transit could result in decreased solute absorption. Although we did not determine transit time along the test segment, reduction in glucose absorption by dihydroxy bile acids has also been observed in a closedloop system which eliminates this variable (9).

Inhibition of active transport processes. It has been postulated that dihydroxy bile acids and fatty acids affect solute transport by inhibiting active transport processes and by enhancing passive absorption $(35,36)$. This general statement does not explain the in vivo observations in the small intestine. Absorption of fatty acids and glucose are affected to a similar degree; however, no active transport process has been demonstrated for fatty acids. Moreover, absorption rates of other compounds for which no active transport mechanisms have been claimed are also affected, such as oxalate (37), arabinose, ${ }^{2}$ urea (38), thiourea (9), and mono-olein (16). This hypothesis also fails to explain how absorption of fatty acids is enhanced as fluid secretion is reduced in the presence of $56 \mathrm{mM}$ glucose (34). This last observation also argues against an alternative explanation that fatty acids and bile acids simply inhibit all transport processes in the villi and thereby unmask normal fluid secretion from the crypts.

Other considerations. Our data indicate that in the presence of dihydroxy bile acids and fatty acids, absorption of micellar and nonmicellar solutes is related to changes in net water movement (Table III). Net fluid secretion in itself cannot explain this phenomenon, since mannitol-induced fluid secretion did not alter the absorption of glucose or OA and since mean segment concentrations of these solutes were higher or unchanged during fluid secretion induced by fatty acids and dihydroxy bile acids. It has been stated that bile acids and hydroxy fatty acids induce net fluid secretion by a cyclic AMP-mediated process $(39,40)$. Net secretion of sodium, however, is an unlikely cause for the reduction in solute absorption since glucose absorption remains intact in the presence of fluid secretion induced by cholera toxin (41), a process also mediated by cyclic AMP (48). If changes in sodium transport were the only cause for water and solute transport under our experimental

\footnotetext{
${ }^{2}$ Brown, B. D., and H. V. Ammon. Unpublished observation.
}

conditions, the slopes for the regression lines between net water and glucose transport should be the same in the presence of OA, RA, and dihydroxy bile acids. In addition, the absorption of passively transported solutes should be independent of sodium fluxes.

Dihydroxy bile acids and other detergents enhance mucosal permeability for glucose at concentrations below which they interfere with the morphological integrity of the mucosa (43). Since dihydroxy bile acids and fatty acids have detergent properties (44), enhancement of mucosal permeability, therefore, might be another possible explanation for the observed changes in solute transport. However, this would not explain why dihydroxy bile acids and fatty acids inhibit solute absorption in the jejunum while they enhance solute absorption in the colon $(36,37,45)$. Frank mucosal damage by itself $(45,46)$ is an unlikely explanation for the observations in the human jejunum, since the changes in water and solute transport are readily reversible. The data at hand, therefore, do not allow formulation of a hypothesis which is able to explain all the effects of fatty acids and bile acids on water and solute transport satisfactorily.

Clinical significance. The present studies provide a possible explanation for the frequently observed steatorrhea in the blind loop syndrome beyond the concept that deconjugation and dehydroxylation of bile acids by bacteria result in a reduction of the intraluminal bile salt concentration below the critical micellar concentration (1-3). Further, since dihydroxy bile acids and fatty acids interfere with the absorption of other solutes as well, our results also explain the frequently observed malabsorption of other nutrients in this condition. Whether other factors such as bacterial toxins play an additional role in the pathogenesis of this syndrome remains to be established.

\section{ACKNOWLEDGMENTS}

We are grateful to Ms. Monica Wnuk and Ms. Louise Luedtke for their expert technical assistance, and we thank Dr. Konrad H. Soergel for reviewing the manuscript.

This investigation was supported in part by research grant AM 17941-01 from the National Institutes of Health, U. S. Public Health Service, and by the Medical Research Service of the Veterans Administration. Dr. Wanitschke was the recipient of a traveling grant from the Paul Martini Stiftung, Frankfurt, Germany.

\section{REFERENCES}

1. Clark, M. L., H. C. Lanz, and J. R. Senior. 1969. Bile salt regulation of fatty acid absorption and esterification in rat everted jejunal sacs in vitro and into thoracic duct lymph in vivo. J. Clin. Invest. 48: 1587-1599.

2. Cheney, F. E., V. Burke, M. L. Clark, and J. R. Senior. 1970. Intestinal fatty acid absorption and esterification from luminal micellar solutions containing deoxycholic acid. Proc. Soc. Exp. Biol. Med. 133: 212-215. 
3. Donaldson, R. M. 1970. Small bowel bacterial overgrowth Adv. Intern. Med. 16: 191-212.

4. Tabaqchali, S., J. Hatzioannou, and C. C. Booth. 1968. Bile salt deconjugation and steatorrhea in patients with the stagnant loop syndrome. Lancet. II: 12-16.

5. Kim, Y. S., N. Spritz, M. Blum, J. Terz, and P. Sherlock. 1966. The role of altered bile acid metabolism in steatorrhea of experimental blind loop. J. Clin. Invest. 45: $956-962$.

6. Ament, M. E., S. S. Shimoda, D. R. Saunders, and C. E. Rubin. 1972. The pathogenesis of steatorrhea in three cases of small intestinal stasis syndrome. Gastroenterology. 63: 728-747.

7. Shimoda, S. S., T. K. O'Brien, and D. R. Saunders. 1974. Fat absorption after infusing bile salts into the human small intestine. Gastroenterology. 67: 7-18.

8. Forth, W., W. Rummel, and H. Glasner. 1966. Zur resorptionshemmenden Wirkung von Gallensäuren. Naunyn-Schmiedebergs Arch. Pharmakol. Exp. Pathol. 254: 364-380.

9. Sladen, G. E., and J. T. Harries. 1972. Studies on the effects of unconjugated dihydroxy bile salts on rat small intestinal function in vivo. Biochim. Biophys. Acta. 288: 443-456.

10. Hajjar, J. J., R. N. Khuri, and A. B. Bikhazi. 1975. Effect of bile salts on amino acid transport by rabbit intestine. Am. J. Physiol. 229: 518-523.

11. Ammon, H. V., and S. F. Phillips. 1974. Inhibition of ileal water absorption by intraluminal fatty acids. J. Clin. Invest. 53: 205-210.

12. Wingate, D. L., S. F. Phillips, and A. F. Hofmann 1973. Effect of glycine conjugated bile acid with and without lecithin on water and glucose absorption in perfused human jejunum.J. Clin. Invest. 52: 1230-1236.

13. Krag, E., and S. F. Phillips. 1974. Effect of free and conjugated bile acids on net water, electrolyte, and glucose movement in the perfused human ileum. $J$. Lab. Clin. Med. 83: 947-956.

14. Ammon, H. V., P. J. Thomas, and S. F. Phillips. 1974 Effects of oleic and ricinoleic acids on net jejunal water and electrolyte movement. J. Clin. Invest. 53: 374-379.

15. Wingate, D. L., E. Krag, H. S. Mekhjian, and S. F. Phillips. 1973. Relationships between ion and water movement in the human jejunum, ileum and colon during perfusion with bile acids. Clin. Sci. Mol. Med. 45: 593-606.

16. Ammon, H. V., P. J. Thomas, and S. F. Phillips. 1977. Effects of long chain fatty acids on solute absorption: perfusion studies in the human jejunum. Gut. In press.

17. Hofmann, A. F. 1963. The function of bile salts in fat absorption: the solvent properties of dilute micellar solutions of conjugated bile salts. Biochem. J. 89: 57-68.

18. Knight, H. B., R. E. Koos, and D. Swern. 1953. Addition of formic acid to olefinic compounds. I. Monoolefinic compounds. J. Am. Chem. Soc. 75: 6212-6215.

19. Phillips, S. F., and W. H. J. Summerskill. 1966. Occlusion of the jejunum for intestinal perfusion in man. Mayo Clin. Proc. 41: 224-231.

20. Krag, E., and S. F. Phillips. 1974. Active and passive bile acid absorption in man. Perfusion studies of the ileum and jejunum. J. Clin. Invest. 53: 1686-1694.

21. Wingate, D. L., R. J. Sandberg, and S. F. Phillips. 1972. A comparison of stable and ${ }^{14} \mathrm{C}$-labelled polyethylene glycol as volume indicators in the human jejunum. Gut. 13: $812-815$.

22. Okita, G. T., J. J. Kabara, F. Richardson, and G. V. LeRoy.
1957. Assaying compounds containing $\mathrm{H}^{3}$ and $\mathrm{C}^{14}$ Nucleonics. 15: 111-114.

23. Cohen, M., R. G. H. Morgan, and A. F. Hofmann. 1969. One-step quantitative extraction of medium-chain and long-chain fatty acids from aqueous samples. J. Lipid Res. 10: 614-616.

24. Goodwin, J. F. 1970. Method for simultaneous direct estimation of glucose and xylose in serum. Clin. Chem. 16: 85-91.

25. Snedecor, G. W., and W. G. Cochran. 1967. Statistical Methods. Iowa State University Press, Ames, Iowa. 5th edition. 91-119.

26. Thomas, P. J. 1972. Identification of some enteric bacteria which convert oleic acid to hydroxy stearic acid in vitro. Gastroenterology. 62: 430-435.

27. Lamabadusuriya, S. P., E. Guiraldes, and J. T. Harries. 1975. Influence of mixtures of taurocholate, fatty acids, and mono-olein on the toxic effects of deoxycholate in rat jejunum in vivo. Gastroenterology. 69: 463-469.

28. Hoffman, N. E., and W. J. Simmonds. 1971. The intestinal uptake and esterification, in vitro, of fatty acid as a diffusion limited process. Biochim. Biophys. Acta. 241: 331-333.

29. Westergaard, H., and J. M. Dietschy. 1976. The mechanism whereby bile acid micelles increase the rate of fatty acid and cholesterol uptake into the intestinal mucosal cell. J. Clin. Invest. 58: 97-108.

30. Wu, A-L., S. B. Clark, and P. R. Holt. 1975. Transmucosal triglyceride transport rates in proximal and distal rat intestine in vitro. J. Lipid Res. 16: 251-257.

31. Ockner, R. K., and J. A. Manning. 1974. Fatty acidbinding protein in small intestine. Identification, isolation, and evidence for its role in cellular fatty acid transport. J. Clin. Invest. 54: 326-338.

32. Simmonds, W. J. 1974. Absorption of lipids. In MTP International Review of Science, Physiology Series One, "Gastrointestinal Physiology." E. D. Jacobson and L. L. Shanbour, editors. University Park Press, Baltimore. 4: 343-376.

33. Dawson, A. M., and K. J. Isselbacher. 1960. Studies on lipid metabolism in the small intestine with observations on the role of bile salts. J. Clin. Invest. 39. 730-740.

34. Brown, B. D., S. L. Broor, and H. V. Ammon. 1977. Influence of net water movement on absorption of oleic acid in the human jejunum. Gastroenterology. 72: 1032. (Abstr.)

35. Frizzell, R. A., and S. G. Schultz. 1970. Effect of bile salts on transport across brush border of rabbit ileum. Biochim. Biophys. Acta. 211: 589-592.

36. Dobbins, J. W., and H. J. Binder. 1976. Effect of bile salts and fatty acids on the colonic absorption of oxalate. Gastroenterology. 70: 1096-1100.

37. Saunders, D. R., J. Sillery, and G. B. McDonald. 1975. Regional differences in oxalate absorption by rat intestine: evidence for excessive absorption by the colon in steatorrhoea. Gut. 16: 543-554.

38. Pope, J. L., T. M. Parkinson, and J. A. Olson. 1966. Action of bile salts on the metabolism and transport of water-soluble nutrients by perfused rat jejunum in vitro. Biochim. Biophys. Acta. 130: 218-232.

39. Binder, H. J., C. Filburn, and B. T. Volpe. 1975. Bile salt alteration of colonic electrolyte transport: role of cyclic adenosine monophosphate. Gastroenterology. 68: 503-508.

40. Binder, H. J. 1974. Cyclic adenosine monophosphate controls bile salt and hydroxy fatty acid-induced colonic electrolyte secretion. J. Clin. Invest. 53: 7a-8a. (Abstr.) 
41. Carpenter, C. C. J., R. B. Sack, J. C. Feeley, and R. W. Steenberg. 1968. Site and characteristics of electrolyte loss and effect of intraluminal glucose in experimental canine cholera. J. Clin. Invest. 47: 1210-1220.

42. Field, M. 1974. Intestinal secretion. Gastroenterology. 66: 1063-1084.

43. Moore, J. D., M. L. Zatzman, and D. E. Overack. 1971. The effects of synthetic surfactants on intestinal permeability to glucose in vitro. Proc. Soc. Exp. Biol. Med. 137: 1135-1139.

44. Small, D. M. 1968. A classification of biologic lipids based upon their interactions in aqueous systems. $J$. Am. Oil Chem. Soc. 45: 108-119.

45. Gaginella, T. S., V. S. Chadwick, J. C. Debongnie, J. C. Lewis, and S. F. Phillips. 1977. Perfusion of rabbit colon with ricinoleic acid: dose-related mucosal injury, fluid secretion, and increased permeability. Gastroenterology: 73: 95-101.

46. Cline, W. S., V. Lorenzsonn, L. Benz, P. Bass, and W. A. Olsen. 1976. The effects of sodium ricinoleate on small intestinal function and structure. J. Clin. Invest. 58: 380-390. 